\author{
Galina KALDA ${ }^{1}$
}

Joanna MURIAS ${ }^{2}$

\title{
ANALIZA ZANIECZYSZCZEŃ WÓD PODZIEMNYCH ODPADAMI ZAKŁADÓW PRZEMYSLOWYCH NA TERENIE WOJEWÓDZTWA PODKARPACKIEGO
}

\begin{abstract}
W artykule prezentowano analizę zanieczyszczeń wód podziemnych odpadami zakładów przemysłowych, jakie mają miejsce w województwie podkarpackim, a same, w Rzeszowie, Stalowej Wole, Przemyślu, Mielcu, Dębice, Tarnobrzegu. Zanieczyszczenia wód podziemnych są najczęściej konsekwencją niezamierzonych zdarzeń, takich jak np. pęknięcia i nieszczelności rurociągów i kanalizacji, uszkodzenia zbiorników $\mathrm{z}$ niebezpiecznymi substancjami, awarie instalacji technologicznych, itp. Przedstawione metody ochrony i monitoringu wód podziemnych przed degradacją. Dominującymi gałęziami przemysłu są przemysł lotniczy, elektromaszynowy, rolno-spożywczy oraz chemiczny. Wskaźniki zanieczyszczenia wód podziemnych w zależności od rodzaju przemysłu są bardzo zróżnicowane. Zależą od charakteru produkcji, wytwarzanych produktów, wykorzystywanych surowców, stosowanych technologii, transportu, magazynowania, metod oczyszczania ścieków, utylizacji odpadów itp. W województwie podkarpackim największa ilość odpadów przemysłowych powstała w powiecie dębickim, stalowowolskim, mieleckim i rzeszowskim. Najmniej odpadów zostało wytworzonych w powiatach lubaczowskim, bieszczadzkim i kolbuszowskim. Miastem o największej ilości odpadów przemysłowych jest Rzeszów. W prace są analizowane zanieczyszczenia wód podziemnych ze względu na wytwarzane odpady przemysłowe i ze względu na składowiska. Jakość wód podziemnych z otworów piezometrycznych umieszczonych na terenie składowisk odpadów przemysłowych zależy od rodzaju deponowanych odpadów. Poprawa jakości wód podziemnych może być związana z modernizacją zabezpieczeń składowisk odpadów przemysłowych.
\end{abstract}

Słowa kluczowe: wody podziemne, zanieczyszczenie, odpady, zakłady przemysłowe

\footnotetext{
${ }^{1}$ Autor do korespondencji/corresponding author: Galina Kalda, Politechnika Rzeszowska, Wydział Budownictwa, Inżynierii Środowiska i Architektury, al. Powstańców Warszawy 6, 35-959 Rzeszów, tel. 17 8651068, kaldagal@prz.edu.pl

2 Joanna Murias, Politechnika Rzeszowska
} 


\section{Wprowadzenie}

Jednym z najważniejszych związków chemicznych występujących w środowisku i niezbędnym dla funkcjonowania wszystkich organizmów jest woda. Szczególne bogactwo narodowe stanowią wody podziemne. Ich skład chemiczny zależy głównie od miejsca występowania, natury ośrodka, jakości wód infiltrujących do skalnego ośrodka, procesów fizyko-chemicznych oraz biogeochemicznych, które zachodzą w warstwie wodonośnej.

Wody podziemne coraz częściej ulegają zanieczyszczeniu lub skażeniu przez odcieki wysypiskowe, ścieki przemysłowe i komunalne gromadzone na wylewiskach nieczystości oraz przez wycieki chemikaliów z cystern i zbiorników paliw. Wraz ze wzrostem zaludnienia i rozwojem przemysłu, wzrasta ilość zanieczyszczeń. Negatywny wpływ na pogorszenie się czystości wód podziemnych może mieć obecność znajdujących się w pobliżu zakładów przemysłowych, a także składowisk odpadów przemysłowych, na których gromadzone są bardzo różne rodzaje odpadów, charakterystyczne dla danego typu przemysłu. Wody podziemne $\mathrm{w}$ rejonie takich składowisk mogą być zanieczyszczone przez wiele różnych substancji chemicznych. Niektóre z nich są bardzo niebezpieczne dla środowiska wodnego. Zmniejszająca się dostępność oraz pogarszająca się jakość wód podziemnych jest problemem rangi światowej.

Ocena jakości wód podziemnych jest procesem złożonym i przeprowadza się ją w oparciu o przyjęte wskaźniki jakości wód. Podstawowym aktem prawnym jest Ustawa „Prawo wodne”, która określa zasady prawidłowego kształtowania, gospodarowania, a także ochronę wód. Wytyczne dotyczące monitoringu, częstotliwości wykonywania badań, klasyfikacji jakości wód zawarte są w rozporządzeniach do tej ustawy. Na ocenę jakości wód podziemnych wpływa wiele różnych czynników, które zostaną szerzej opisane w artykule wraz z procesem oceny jakości wód.

\section{Zanieczyszczenia wód podziemnych}

Zanieczyszczenie wód podziemnych występuje, gdy następuje niekorzystna zmiana ich cech chemicznych, fizycznych lub bakteriologicznych. Zmiany te mogą być wywołane poprzez bezpośrednie wprowadzenie substancji zanieczyszczających do wód, a także pośrednio przez przemieszczanie się wód zanieczyszczonych do ujęcia. Do zanieczyszczeń zagrażających bezpośrednio należą studnie chłonne, zalane kopalnie, składowiska podpoziomowe itp. Pośrednio zagrażające są oddzielone i w większym lub mniejszym stopniu izolowane od wód podziemnych. Zanieczyszczenia wód podziemnych są najczęściej konsekwencją niezamierzonych zdarzeń, takich jak np. pęknięcia i nieszczelności rurociągów i kanalizacji, uszkodzenia zbiorników z niebezpiecznymi substancjami, awarie instalacji technologicznych, itp. Zanieczyszczenia pochodzące z przemysłu, gospodarki komunalnej, rolnictwa, hodowli i transportu są zasadniczymi rodzajami zanieczyszczeń wód podziemnych. 
Zanieczyszczenia wód podziemnych ze względu na pochodzenie można zakwalifikować do jednej z grup:

- zanieczyszczenia geogeniczne - pojawiają się w wyniku geologicznych i przyrodniczych uwarunkowań, gdy substancja zanieczyszczająca ma naturalne pochodzenie, np. ze szkieletu gruntowego warstwy wodonośnej;

- zanieczyszczenia antropogeniczne - są wynikiem bezpośredniego wprowadzania niektórych substancji do wód podziemnych, głównie poprzez działalność i bytowanie człowieka. od:

Zagrożenie wód podziemnych zanieczyszczeniem zależy przede wszystkim

- warunków środowiska, w których zachodzi migracja (zewnętrznych czynników migracji), takich jak ciśnienie, temperatura, odczyn, potencjał utleniająco-redukcyjny, rodzaj i stężenie innych substancji w wodzie, itp.,

- właściwości (aktywności chemicznej, trwałości, itp.) potencjalnych zanieczyszczeń lub rzeczywistych, zależnie od ich budowy i składu chemicznego (tzw. czynniki wewnętrzne migracji),

- warunków hydrogeologicznych występowania wód podziemnych.

Zanieczyszczenia mogą przenikać bezpośrednio lub pośrednio do wód podziemnych różnymi drogami. Rozróżnia się kilka schematów potencjalnej migracji substancji niepożądanych:

- bezpośrednia migracja zanieczyszczeń do warstwy wodonośnej ze składowisk, studni chłonnych, których stopa znajduje się poniżej poziomu wód podziemnych, poprzez niezabezpieczone otwory wiertnicze i studnie, kopalnie zatapiane itp.,

- pionowa migracja zanieczyszczeń z jednej warstwy wodonośnej do drugiej przez hydrauliczne kontakty pomiędzy poszczególnymi warstwami wodonośnymi (przesiąkanie przez warstwy słabo przepuszczalne, okna hydrogeologiczne itp.).

- migracja zanieczyszczeń do warstwy wodonośnej przez strefę aeracji, głównie ze składowisk i wylewisk odpadów, które są zlokalizowane powyżej zwierciadła wód podziemnych, z terenów rolniczych oraz innego typu źródła zanieczyszczeń zlokalizowanych na powierzchni ziemi, a także infiltracja opadów zanieczyszczonych (np. kwaśne deszcze),

- boczny dopływ zanieczyszczeń z obszarów zanieczyszczonych, infiltracja wód powierzchniowych, uruchomienie ognisk zanieczyszczeń w tej samej warstwie wodonośnej [1].

Źródła zanieczyszczenia wód podziemnych nazwane są ogniskami zanieczyszczeń. Ogólnie dzielone są na ogniska związane i niezwiązane ze składowaniem odpadów. Przyczyną degradacji jakości wód podziemnych zwaną geogeniczną jest również napływ słonych wód głębinowych do środowiska słodkich wód oraz ingresja zasolonych wód morskich w obręb słodkowodnych zbiorników wód podziemnych. Do źródeł degradacji wód podziemnych należą także zanieczyszczone opady atmosferyczne oraz opad pyłów na powierzchnię ziemi [2]. 
Ważnym źródłem degradacji płytkich wód podziemnych są opady pyłów przemysłowych oraz zanieczyszczone opady atmosferyczne. Zakwaszenie opadów atmosferycznych sprzyja uruchomieniu niektórych składników obecnych w glebie oraz przenoszeniu ich w głąb do wód gruntowych. Zanieczyszczenia $\mathrm{z}$ atmosfery nie mogą być skutecznie ograniczane bez redukcji emisji tych zanieczyszczeń [2].

Składowiska odpadów przemysłowych są dużym zagrożeniem dla wód podziemnych, zarówno istniejące jak i nieczynne, zwłaszcza te, które zostały wadliwie zaprojektowane i bez właściwych zabezpieczeń ograniczających ich negatywny wpływ na środowisko. Czynnikiem transportującym zanieczyszczenia z wysypisk przemysłowych do wód podziemnych są odcieki z odpadów. Zanieczyszczenia, które wraz z odciekami przedostaną się do warstwy wodonośnej, pozostają tam długo i są trudne lub niemożliwe do usunięcia. Istotne znaczenie z punktu widzenia przemian, zachodzących w składowiskach odpadów przemysłowych, ilości i składu chemicznego powstających odcieków, a także stopnia oddziaływania składowiska na środowisko wodne ma skład chemiczny odpadów [3,4].

\section{Ochrona i monitoring wód podziemnych przed degradacją}

Ochrona wód podziemnych - to działalność zmierzająca do zapewnienia dostatecznej ilości oraz odpowiedniej jakości wód podziemnych. Rozróżnia się ochronę czynną i bierną wód podziemnych. Elementami ochrony biernej wód podziemnych są tzw. strefy ochronne. Obowiązują w nich ograniczenia i zakazy różnych czynności gospodarczych, które mogłyby doprowadzić do degradacji jakości tych wód (np. nawożenia, wiercenia, działalności górniczej itp.). W strefie ochronnej biernej elementem czynnym może być nakaz zabezpieczenia lub usunięcia potencjalnego ogniska zagrożenia czystości wód podziemnych. Profilaktyka ochronna polega głównie na tworzeniu odpowiednich stref ochronnych oraz na zakładaniu sieci obserwacyjno-kontrolnej. Środki ochrony czynnej nie zawsze są podejmowane, ponieważ ich realizacja związana jest z ogniskami zanieczyszczeń i musi być ściśle dostosowana do hydrogeologicznych warunków oraz do technicznych możliwości $[2,5]$.

Państwa należące do Unii Europejskiej mają obowiązek prowadzenia monitoringu w zakresie stanu, gospodarowania i ochrony zasobami wodnymi, zgodnie z Ramową Dyrektywą Wodną (RDW, 2000/60/WE). Zgodnie z art. 8, kraje zobowiązane są do ustanowienia sieci monitoringu wód. Badania jakości wód podziemnych w sieci krajowej prowadzi Państwowy Instytut Geologiczny, który jest zobligowany do wykonywania badań wód podziemnych, z mocy ustawy „Prawo wodne”. Wyniki badań gromadzone są w komputerowej bazie danych MONBADA [6,7].

Monitoring wód podziemnych polega na ciągłej kontroli ich cech fizycznochemicznych i wchodzi w zakres informacji uzyskiwanych w ramach państwowego monitoringu środowiska [2]. 
W systemie monitoringu państwowego sieć obserwacyjną wód podziemnych stanowią: stacje i posterunki hydrogeologiczne, punkty monitoringu jakości wód podziemnych, piezometry oraz obudowane źródła (studnie) [1].

Składowiska odpadów jako obiekty znacznie zagrażające wodom podziemnych powinny być wyposażone w odpowiednio zorganizowany monitoring tych wód. Założenie monitoringu powinno być regułą dla wszystkich składowisk niezależnie od ich technicznego wyposażenia [8].

Monitoring wód podziemnych na terenie składowisk odpadów ma na celu śledzenie zmian jakości tych wód oraz przeciwdziałanie negatywnemu oddziaływaniu składowisk na wody podziemne.

\section{Analiza zanieczyszczenia wód podziemnych ze względu na wytwarzane odpady przemysłowe na terenie województwa podkarpackiego}

W porównaniu z innymi regionami Polski, zasoby wód podziemnych na terenie Podkarpacia są niewielkie. Wody te są rozmieszczone nierównomiernie i mają nieocenione znaczenie gospodarcze. Są istotnym rezerwuarem wód pitnych dla mieszkańców, przemysłu spożywczego, a także hodowli. Związane są z dużymi jednostkami geologicznymi, które jednocześnie stanowią hydrogeologiczne regiony.

Z występujących na obszarze województwa podkarpackiego trzech poziomów wodonośnych zwykłych wód podziemnych, największe znaczenie mają wody, które są ujmowane z utworów czwartorzędowych. Natomiast wody w utworach trzeciorzędowych i kredowych wykorzystywane są w niewielkim stopniu. Większość zasobów rozmieszczonych jest w dziewięciu Głównych Zbiorników Wód Podziemnych (GZWP), które występują w całości lub we fragmentach na terenie województwa. Najwięcej zasobów wód podziemnych (ok. 80\%) występuje w części północnej województwa [10].

Według Głównego Urzędu Statystycznego, zasoby eksploatacyjne wód podziemnych w województwie podkarpackim wynoszą $506,1 \mathrm{hm}^{3}$, co stanowi 2,93\% zasobów krajowych.

Na terenie województwa jakość wód podziemnych głównych zbiorników wodonośnych jest bardzo zróżnicowana. Zbiorniki kredowe i trzeciorzędowe na ogół charakteryzują się średnią i wysoką jakością wód. W zbiornikach czwartorzędowych jakość wód jest zdecydowanie gorsza, ponieważ występowanie podwyższonych zawartości wodorowęglanów i żelaza jest dość powszechne. Występuje także antropogeniczne zanieczyszczenie wyrażone najczęściej podwyższoną zawartością związków azotu. Słaba naturalna izolacja poziomu wodonośnego w zbiornikach czwartorzędowych powoduje, że są one narażone na migrację zanieczyszczeń z atmosfery, lokalnych źródeł punktowych, rolnictwa, aglomeracji miejskich i przemysłowych [10]. 
Jedną z przyczyn zanieczyszczenia wód podziemnych na terenie województwa podkarpackiego są tereny zakładów przemysłowych, na których są składowane odpady oraz przelewane lub transportowane substancje niebezpieczne.

Dominującymi gałęziami przemysłu są przemysł lotniczy, elektromaszynowy, rolno-spożywczy oraz chemiczny. Łącznie wytwarzają one około $70 \%$ produkcji przemysłowej na Podkarpaciu. Istotną rolę odgrywają również przemysł drzewny, materiałów budowlanych, szklarski oraz przemysł lekki. Do najważniejszych ośrodków przemysłowych, które odgrywają dominującą rolę w rozwoju gospodarczym w regionie należą miasta: Rzeszów, Stalowa Wola, Przemyśl, Mielec, Dębica, Tarnobrzeg, Krosno i Jasło.

Rzeszów jest największym miastem oraz ośrodkiem przemysłowym z dominantą przemysłu rolno-spożywczego i elektromaszynowego w województwie. Głównymi przedstawicielami tych przemysłów są: Wytwórnia Sprzętu Komunikacyjnego „PZL-Rzeszów” S.A. - producent silników lotniczych, Zelmer S.A. producent sprzętu AGD, Nestle Nutrition Alima-Gerber S.A. - producent odżywek i soków dla dzieci oraz ICN Polfa Rzeszów S.A. - producent farmaceutyków.

Stalowa Wola jest wyspecjalizowanym ośrodkiem przemysłowym głównie w przemyśle maszynowym, metalurgicznym i energetycznym. Funkcjonują tu m.in.: Huta Stalowa Wola S.A. z zakładami metalurgicznymi (Kuźnią, Ciągarnią, Odlewnią, Zakład Zespołów Mechanicznych), Elektrownia „Stalowa Wola” S.A.

W Przemyślu ważniejszymi przemysłowymi przedsiębiorstwami są: Zakłady Wyrobów Powlekanych „SANWIL” S.A., Fanina - producent aparatury elektromechanicznej, Zakłady Płyt Pilśniowych S.A. - producent płyt pilśniowych, Zakłady Automatyki „POLNA” S.A. - specjalizujący się w automatyce przemysłowej.

W Mielcu główną siłą sektora przemysłowego jest Specjalna Strefa Ekonomiczna „EURO-PARK Mielec”. Funkcjonuje w niej wiele firm o zróżnicowanym charakterze usług i produkcji. Ważniejszymi zakładami przemysłowymi w Mielcu są Polskie Zakłady Lotnicze Sp. z o.o., które powstały w wyniku restrukturyzacji WSK „PZL” Mielec oraz Zakład Produkcji Paliwa Alternatywnego „EURO-EKO” Sp. z o.o.

Dębica jest ośrodkiem przemysłowym wyspecjalizowanym w przemyśle chemicznym, gumowym, metalowym i spożywczym. Do najważniejszych zakładów przemysłowych należą: Firma Oponiarska „TC Dębica” S.A., Fabryka Farb, Lakierów i Klejów „CHEMSTAL” sp. z o.o., Tikkurila Polska S.A.„Polifarb Dębica” - producent farb, wyrobów lakierowych i żywic, Wytwórnia Urządzeń Chłodniczych „PZL-Dębica” S.A.

Tarnobrzeg pełni rolę ośrodka przemysłowego, opartego głównie na górnictwie i przetwórstwie siarki. Jednym z najważniejszych przedsiębiorstw są ZAKŁADY CHEMICZNE „Siarkopol” TARNOBRZEG sp. z o.o., zajmujące się m.in. produkcją nawozów mineralnych i siarki, które powstały w wyniku restrukturyzacji Kopalń i Zakładów Przetwórczych Siarki „SIARKOPOL”. 
Krosno jest największym w kraju ośrodkiem przemysłu szklarskiego. W Krośnie i okolicy eksploatowane są złoża gazu ziemnego i ropy naftowej. Rozwija się także przemysł meblarski.

Wskaźniki zanieczyszczenia wód podziemnych w zależności od rodzaju przemysłu są bardzo zróżnicowane. Zależą od charakteru produkcji, wytwarzanych produktów, wykorzystywanych surowców, stosowanych technologii, transportu, magazynowania, metod oczyszczania ścieków, utylizacji odpadów itp. Województwo podkarpackie jest województwem o jednym z najniższych wskaźników ilości wytwarzania odpadów. W 2014 roku, według danych Głównego Urzędu Statystycznego, 111 zakładów z terenu województwa wytworzyło 2 093,7 tys. Mg odpadów przemysłowych. Odpady te stanowiły niespełna 1,7\% ogółu tego rodzaju odpadów w skali kraju [11].

W województwie podkarpackim największa ilość odpadów przemysłowych powstała w powiecie dębickim, stalowowolskim, mieleckim i rzeszowskim. Najmniej odpadów zostało wytworzonych w powiatach lubaczowskim, bieszczadzkim i kolbuszowskim. Miastem o największej ilości odpadów przemysłowych jest Rzeszów. Wytworzone odpady na Podkarpaciu zostały poddane głównie odzyskowi (94,8\%), 2,1\% było czasowo magazynowane, zaś 3,1\% odpadów unieszkodliwiono termicznie, przez składowanie lub kompostowanie. Obszary składowania odpadów w województwie podkarpackim stanowią tereny zrekultywowane (1,3 ha) i niezrekultywowane (34 ha) [11].

\section{Analiza zanieczyszczenia wód podziemnych ze względu na składowiska odpadów przemysłowych w województwie podkarpackim}

Badaniami objęto składowiska odpadów, a także tereny zakładów przemysłowych, stanowiących potencjalne zagrożenie dla wód podziemnych. Pobór próbek wód odbywał się z piezometrów rozmieszczonych wokół wymienionych poniżej obiektów. Analizowane obiekty objęte badaniami: Zakład Produkcji Paliwa Alternatywnego firmy „EURO-EKO” Sp. z o.o. Mielec - teren SSE „EURO-PARK” Mielec; Zakłady Tworzyw Sztucznych GAMRAT S.A. w Jaśle; Huta Stalowa Wola S.A.; ZAKŁADY CHEMICZNE „Siarkopol” TARNOBRZEG Sp. z o.o. - dawniej Kopalnie i Zakłady Przetwórcze Siarki „SIARKOPOL” (w likwidacji) w Tarnobrzegu.

Ocenę jakości wód podziemnych w rejonie składowisk wykonano na podstawie wyników badań monitoringowych przeprowadzanych i udostępnionych przez Wojewódzki Inspektorat Ochrony Środowiska w Rzeszowie oraz w oparciu o odpowiednie akty prawne.

Zakres badań wód podziemnych wokół składowisk odpadów był zgodny z Rozporzadzeniem Ministra Środowiska z dnia 30 kwietnia 2013 r. w sprawie sktadowisk odpadów (Dz. U. 2013 poz. 523). 
Oceny jakości wód podziemnych wokół badanych obiektów dokonano zgodnie z Rozporzadzeniem Ministra Środowiska z dnia 23 lipca 2008 roku (Dz. U. $2008 \mathrm{Nr}$ 143, poz.896) w sprawie kryteriów i sposobu oceny stanu wód podziemnych. Klasyfikacja elementów fizyko-chemicznych stanu wód podziemnych, zawarta w rozporządzeniu, obejmuje pięć klas jakości wód podziemnych.

Klasy I, II i III jakości wód podziemnych określa się dobrym stanem chemicznym, natomiast klasy IV i V słabym stanem chemicznym wód podziemnych [13].

„EURO-EKO” Sp. z o.o. jest Spółką Agencji Rozwoju Przemysłu S.A. w Warszawie, która w 2000 r. została powołana do obsługi infrastruktury wodno-ściekowej oraz gospodarki odpadami na terenie Specjalnej Strefy Ekonomicznej (SSE) „EURO-PARK” Mielec. W 2011 r. ze Spółki „EURO-EKO” została wydzielona zorganizowana część przedsiębiorstwa związana z infrastrukturą wodno-ściekową o nazwie „EURO-EKO MEDIA” Sp. z o.o. Spółka ta przejęła całość działalności związanej z obsługą SSE „EURO-PARK” Mielec (dostawa wody, odbiór i neutralizacja ścieków, usługi w zakresie remontów i wykonawstwa instalacji przemysłowych). Podstawową działalnością ,EUROEKO” po wydzieleniu „EURO-EKO MEDIA” jest odzysk odpadów w procesie produkcji paliw alternatywnych. Wykorzystywane są do tego celu odpady przemysłowe inne niż niebezpieczne, odpady płynne i stałe niebezpieczne, a także odpady komunalne.

Składowisko odpadów przemysłowych w Mielcu zlokalizowane jest w północnej części terenów SSE „EURO-PARK”. Położone jest w bezpośrednim sąsiedztwie lotniska. Jest obiektem posiadającym wymagane zabezpieczenia przed przenikaniem zanieczyszczeń do środowiska gruntowo-wodnego. W podłożu występuje sztuczna warstwa żelbetowa o grubości $0,6 \mathrm{~m}$ (żelbet $\mathrm{z}$ dodatkiem hydrobetu). Całkowita powierzchnia obiektu wynosi 0,08 ha, zaś pojemność wynosi 5954,0 Mg. Na składowisku przyjmowane są odpady przemysłowe eksploatowane (inne niż niebezpieczne i obojętne) z jednostek działających w SSE w Mielcu, m.in. z zakładu „EURO-EKO” Sp. z o.o. Na składowisku funkcjonuje wydzielony sektor na odpady niebezpieczne. Rocznie na składowisku gromadzi się około $0,6 \mathrm{Mg}$.

Składowisko odpadów przemysłowych w Mielcu objęte jest programem badań monitoringowych $\mathrm{w}$ ramach, których prowadzone są monitoringi wód odciekowych i podziemnych. Pomiary do badań monitoringu jakości wód podziemnych zostały wykonane jeden raz na kwartał. Punkty pomiarowe w latach 2013-2014 stanowiły cztery piezometry: Piezometr 1E na napływie wód podziemnych - zlokalizowany na terenie lotniska; Piezometr 3E na odpływie wód podziemnych ze składowiska - zlokalizowany pomiędzy nieczynnym składowiskiem odpadów komunalnych, a zbiornikami odpadów przemysłowych; Piezometr 4E na odpływie wód podziemnych od strony zachodniej - zlokalizowany obok zbiorników odpadów przemysłowych (studzienka wód drenażowych K-1); Piezometr 5E na odpływie wód podziemnych z terenu ZPPA - zlokalizowany na granicy instalacji. 
Ocenę stanu wód podziemnych w rejonie składowiska odpadów przemysłowych w Mielcu wykonano na podstawie wyników badań monitoringowych prowadzonych w otoczeniu obiektu w latach 2013 do 2014. W analizowanym okresie badawczym, analizy w zakresie pomiaru zawartości odczynu, przewodności elektrolitycznej właściwej i zawartości chromu wykonało Laboratorium „EURO-EKO MEDIA” Sp. z o.o., natomiast oznaczenie pozostałych wskaźników przeprowadziło Laboratorium Wojewódzkiego Inspektoratu Ochrony Środowiska w Rzeszowie w 2013 r. i WESSLING Polska Sp. z o.o. Laboratoria Ochrony Środowiska w 2014 r.

W próbkach wód podziemnych pobranych z piezometru 1E odczyn ulega okresowym zmianom w zakresie od słabo kwaśnego do słabo zasadowego. W przeciągu analizowanych lat obserwuje się nieznaczny wzrost, a następnie obniżenie wartości przewodności elektrolitycznej właściwej (PEW) z 142,03 do $111,78 \mu \mathrm{S} / \mathrm{cm}$. Badania wykazały występowanie niskich stężeń wszystkich $\mathrm{z}$ badanych metali. Najwyższe stężenie cynku wynosiło $0,23 \mathrm{mgZn} / \mathrm{dm}^{3}$, natomiast miedzi $0,0148 \mathrm{mgCu} / \mathrm{dm}^{3}$. Pozostałe badane metale: chrom, kadm, ołów i rtęć, występowały w śladowych ilościach oraz ilościach poniżej granicy oznaczalności. Również zawartość sumy wielopierścieniowych węglowodorów aromatycznych (WWA) wykazywała ich zawartość w ilości poniżej granicy oznaczalności, następnie zaś nastąpił wzrost do $0,176 \mu \mathrm{g} / \mathrm{dm}^{3}$ i obniżenie zawartości do $0,00016 \mu \mathrm{g} / \mathrm{dm}^{3}$. Wskaźnikiem ulegającym wyraźnej zmianie jest węgiel organiczny ogólny (OWO), którego ilość wzrosła do poziomu $12,8 \mathrm{mgC} / \mathrm{dm}^{3}$. W 2013 r. wody podziemne w piezometrach 1E, 3E i 4E były bardzo dobrej jakości (I klasa), natomiast w piezometrze 5E woda była dobrej jakości (II klasa). W 2014 r. nastąpiło pogorszenie jakości wód w piezometrach zlokalizowanych na odpływie wód podziemnych. Jakość wody nie uległa zmianie jedynie w piezometrze 1E zlokalizowanym na napływie wód podziemnych (I klasa). Woda w piezometrze 3E zakwalifikowana została do klasy II. O takiej klasyfikacji zadecydowały OWO i WWA. Wskaźniki te również w piezometrze 4E zadecydowały o jakości wody, która została zakwalifikowana do III klasy (wody zadowalającej jakości). Jakość wody w piezometrze 5E jest niezadowalająca (IV klasa), na co wpłynęły wskaźniki OWO w klasie V oraz WWA. W 2013 r. stan chemiczny wód podziemnych we wszystkich piezometrach uznano za dobry. W 2014 r. w otworach piezometrycznych 1E i 3E stan chemiczny wód podziemnych nie uległ zmianie, natomiast w $4 \mathrm{E}$ i 5E uznano za słaby. Najwyższe wartości przewodności elektrolitycznej właściwej wystąpiły w piezometrze 5E, zlokalizowanym na odpływie wód podziemnych z terenu Zakładu Produkcji Paliwa Alternatywnego „EURO-EKO” Sp. z o.o. Wartości te są znacznie wyższe niż w pozostałych otworach piezometrycznych. W piezometrze $1 \mathrm{E}$ na napływie wód podziemnych odnotowano najniższe wartości tego parametru. Analiza wykazała istotne różnice dla przewodności pomiędzy wodami napływającymi, a odpływającymi, co sugeruje, iż były one zanieczyszczone na obszarze oddziaływania składowiska. 
Wysokie wartości przewodności elektrolitycznej właściwej są związane z antropogenicznym lub geogenicznym zanieczyszczeniem wód podziemnych. W płytkich wodach podziemnych, narażonych na zanieczyszczenia, wartość wskaźnika powyżej $1000 \mu \mathrm{S} / \mathrm{cm}$ wskazuje na możliwość zanieczyszczenia wód. Przewodność właściwa jest parametrem dobrze charakteryzującym zawartość substancji mineralnych [14].

Pomiar ogólnego węgla organicznego udziela informacji o zawartości wszystkich substancji organicznych, tj. wszystkich zanieczyszczeń zawierających ten składnik. WWA występujące w wodach podziemnych może być pochodzenia antropogenicznego i naturalnego. WWA mogą przenikać do wód podziemnych $\mathrm{w}$ większych stężeniach $\mathrm{w}$ pobliżu ognisk zanieczyszczeń, które emitują WWA przez powietrze (sadza i pyły), a także odpady stałe i ciekłe. Do takich ognisk zanieczyszczeń należy analizowany zakład przemysłowy.

Zakłady Tworzyw Sztucznych GAMRAT S.A. w Jaśle zajmują się produkcją najwyższej jakości materiałów budowlanych z polichlorku winylu oraz polietylenu. Materiały te przeznaczone są głównie na potrzeby budownictwa infrastrukturalnego, a także użyteczności publicznej. Produkowane są m.in. systemy rynnowe, podsufitki, okładziny ścienne, wykładziny systemy rurowe. Składowisko odpadów przemysłowych ZTS GAMRAT S.A. w Jaśle zlokalizowane jest w południowowschodniej części zakładu. Położone jest w rejonie niewielkich wzniesień pokrytych lasem. Obiekt posiada wymagane uszczelnienie przed przenikaniem zanieczyszczeń do środowiska gruntowego i wodnego. W podłożu występuje naturalna warstwa gliniasto-pylista, która nie dopuszcza do kontaktu hydraulicznego między wodami powierzchniowymi a wodami związanymi z niżej zalegającą warstwą żwirową, a także sztuczną warstwą gliny o grubości $30 \mathrm{~cm}$. Całkowita powierzchnia składowiska wynosi 0,6 ha, a pojemność $10000 \mathrm{Mg}$. Ilość składowanych odpadów w 2012 r. wynosiła 100,0 Mg, w 2013 r. - 152 Mg, zaś w 2014 r. $117,5 \mathrm{Mg}$. Na składowisku przyjmowano odpady przemysłowe eksploatowane, inne niż niebezpieczne i obojętne. Głównie były to odpady tworzyw sztucznych oraz odpady z kształtowania i powierzchniowej obróbki metali.

Składowisko odpadów przemysłowych ZTS GAMRAT S.A. w Jaśle objęte jest programem badań monitoringu wód powierzchniowych i podziemnych. Badania wód podziemnych wykonywane były z częstotliwością co trzy miesiące w zakresie: odczynu; przewodności elektrolitycznej właściwej; zawartości fenoli; zawartości żelaza.

Próbki wód pobrano z czterech odwiertów piezometrycznych, zlokalizowanych na terenie zakładu przemysłowego: P-1, P-5 - na odpływie wód podziemnych; P-2, P-3, P-4 - na napływie wód podziemnych.

Stan wód podziemnych na terenie składowiska odpadów w Jaśle oceniono na podstawie wyników badań monitoringowych prowadzonych w latach 2012 do 2014. Monitoring wód podziemnych został przeprowadzony w oparciu o Rozporzadzenie MŚ z dnia 23 lipca 2008 roku w sprawie kryteriów i sposobu oceny stanu wód podziemnych. 
Na podstawie badań stwierdzimy, że w wodach podziemnych na obszarze składowiska odpadów ZTS Gamrat S.A. w latach 2012-2014 stwierdzono występowanie wód zróżnicowanej jakości. W badanych piezometrach stwierdzono następującą jakość:

- piezometr P-1 położony na odpływie wód podziemnych - wody w 2012 i 2014 r. zostały zakwalifikowane do klasy III (wody zadowalającej jakości), natomiast w 2013 r. do klasy II (wody dobrej jakości). O klasyfikacji tej zadecydowała zawartość żelaza w wodzie w II klasie (2013 r.), w III klasie (2012 r.) i w IV klasie (2014 r.);

- piezometr P-2 położony na napływie wód podziemnych - jakość wody w 2012 i 2014 r. odpowiadała II klasie, na klasyfikację wpłynęła zawartość żelaza w klasie II. W 2013 r. wody były bardzo dobrej jakości (I klasa);

- piezometr P-3 zlokalizowany na napływie wód podziemnych - w $2012 \mathrm{r}$. stwierdzono wody dobrej jakości (II klasa). W 2013 i 2014 r. jakość wody uległa pogorszeniu i została zaliczona do IV klasy - wody o jakości niezadowalającej. O klasyfikacji tej zadecydowała zawartość fenoli w V klasie i zawartość żelaza w III klasie (2013 r.) oraz stężenie żelaza w V klasie (2014 r.);

- piezometr P-4 na napływie wód podziemnych - w 2012 r. wody uznano za dobrej jakości (II klasa) ze względu na zawartość fenoli w III klasie. W latach 2013- 2014 jakość wód uległa poprawie i została zaliczona do wód bardzo dobrej jakości, czyli I klasy;

- piezometr P-5 na spływie wód podziemnych - wody w 2012-2014 r. odpowiadały klasie III (wody zadowalającej jakości) o czym zadecydowały wartości żelaza w III klasie (2012 i 2014 r.) oraz zawartość fenoli w V klasie (2013 r.).

Stan chemiczny wód uznano za dobry w piezometrach P-1, P-2, P-4 i P-5 w latach 2012-2014 oraz w piezometrze P-3 w 2012 r. W 2013 i 2014 r. stan chemiczny wody w otworze piezometrycznym P-3 uznano za słaby.

Przeprowadzone badania w latach 2012-2014 wykazały, że w piezometrach P-1 i P-5, zlokalizowanych na odpływie wód podziemnych wartości przewodności elektrolitycznej właściwej są znacznie wyższe niż w pozostałych piezometrach, na napływie wód podziemnych. Oznacza to, że w rejonie oddziaływania składowiska wody uległy zanieczyszczeniu. Najniższe wartości PEW wystąpiły w wodzie w piezometrze P-3.

Przewodność elektrolityczna właściwa jest wskaźnikiem mówiącym o wielkości mineralizacji wód, a zatem w przypadku obecności składowiska odpadów także o poziomie zanieczyszczenia [13].

Analizowany Zakład Tworzyw Sztucznych GAMRAT S.A produkujący materiały z tworzyw sztucznych wytwarza ścieki, w których występują fenole. Antropogeniczne ogniska zanieczyszczeń fenolami są często źródłem wielokrotnie wyższych stężeń tych substancji w wodach podziemnych, niż naturalne źródła. Fenole stanowią ważną oraz często spotykaną substancję w przemyśle chemicznym. Ze względu na zawartość żelaza w badanej wodzie podziemnej naj- 
większe stężenie odnotowano $\mathrm{w}$ wodzie pobranej z piezometru P-3 w czerwcu 2014 r., które przekroczyło obowiązujące normy. Najniższe wartości stężeń żelaza występowały w wodzie pobranej z piezometru P-4.

Wysokie stężenia żelaza mogą powstawać pod wpływem czynników antropogenicznych lub z przyczyn naturalnych. Wysokim stężeniom żelaza sprzyjają środowiska kwaśne. Żelazo jest pierwiastkiem o wysokim stopniu potencjalnego zagrożenia. Dotyczy to zwłaszcza wód w utworach czwartorzędowych, o zwiększonej zawartości substancji organicznej. Głównie takie wody występują w województwie podkarpackim.

Huta Stalowa Wola S.A. jest producentem oraz dostawcą wyrobów wojskowych w działalności projektowej, produkcyjnej, konstrukcyjnej i handlowej. Zakład funkcjonuje od 1938 r. HSW S.A. specjalizuje się w sprzęcie artyleryjskim, transporterach opancerzonych, sprzęcie inżynieryjnym oraz uzbrojeniu.

Składowisko odpadów przemysłowych w Stalowej Woli objęte jest programem badań monitoringowych wód podziemnych. Pomiary do badań monitoringu jakości wód podziemnych zostały wykonane raz na kwartał. Punkty pomiarowe w latach 2012-2014 stanowiły cztery odwierty piezometryczne: P-6, P-7, P-8, P-9a, zlokalizowane wokół składowiska odpadów w Stalowej Woli.

Przewodność elektrolityczna występowała w wodach w I klasie w przedziale od 150 do $359 \mu \mathrm{S} / \mathrm{cm}$, nie odnotowano znaczących wzrostów ani spadków. Stężenie manganu w 2012 r. ulegało stopniowemu obniżaniu. W 2013 r. wartości Mn utrzymywały się na poziomie odpowiadającym I klasie. W marcu $2014 \mathrm{r}$. stężenie tego pierwiastka wzrosło do wartości $0,254 \mathrm{mg} / \mathrm{dm}^{3}$ (II klasa), a podczas następnych pomiarów ulegało obniżaniu. Wartości żelaza w 2012 r. mieściły się w granicach 3,43 do $7,43 \mathrm{mg} / \mathrm{dm}^{3}$, a w $2013 \mathrm{r}$. utrzymywały się na poziomie $<0,06 \mathrm{mg} / \mathrm{dm}^{3}$. W lipcu $2014 \mathrm{r}$. stężenie tego wskaźnika osiągnęło wartość $6,92 \mathrm{mg} / \mathrm{dm}^{3}$, a podczas następnych pomiarów jego zawartość się zmniejszała. W ilościach poniżej limitu detekcji, bądź w śladowych ilościach występują: chrom, ołów, rtęć, kadm i WWA. Analiza siarczanów wykazała, że jego zawartość kształtowała się w zakresie $26,9-98,3 \mathrm{mg} / \mathrm{dm}^{3}$. Oznaczenia chlorków wykazały, że występuje on $\mathrm{w}$ granicach tła hydrogeotechnicznego $\left(2-60 \mathrm{mg} / \mathrm{dm}^{3}\right)$, bądź poniżej progu wykrywalności $\left(<0,05 \mathrm{mg} / \mathrm{dm}^{3}\right)$. Od marca $2012 \mathrm{r}$. do lipca $2013 \mathrm{r}$. odnotowano spadek zawartości cynku, następnie wzrost do $0,236 \mathrm{mg} / \mathrm{dm}^{3}$ (marzec $2014 \mathrm{r}$.) i ponownie spadek do $0,037 \mathrm{mg} / \mathrm{dm}^{3}$ w listopadzie 2014 r. Stwierdzono niskie zawartości miedzi w badanej wodzie. Wskaźnikiem wykazującym duże zmiany jest zawartość niklu. W 2013 r. wartości metalu były kilkakrotnie niższe niż w pozostałych latach. W 2012 i 2014 r. stężenie Ni ulegało obniżaniu podczas kolejnych pomiarów. OWO charakteryzował się znaczną zmiennością w 2014 r. Stwierdzono na przemian występujące podwyższenie i obniżenie ilości tego parametru. W latach wcześniejszych ogólny węgiel organiczny występował w przedziale od 2 do $6,3 \mathrm{mg} / \mathrm{dm}^{3}$.

Stan chemiczny wód podziemnych w latach 2012-2014 uznano za dobry w otworach piezometrycznych P-8 i P-9a, natomiast za słaby w P-6 i P-7. 
W badanej wodzie podziemnej najwyższe stężenia manganu zaobserwowano w piezometrze P-6 i P-9a. Stężenie tego parametru w wodzie pobranej z pozostałych otworów piezometrycznych utrzymywała się na zbliżonym poziomie.

Metan jest pierwiastkiem o wysokim stopniu potencjalnego zagrożenia. $\mathrm{W}$ wodach podziemnych występuje przeważnie w zawartościach od 0,01 do 0,4 $\mathrm{mg} / \mathrm{dm}^{3}$ [13]. W badanej wodzie na terenie składowiska odpadów przemysłowych w Stalowej Woli stężenia manganu mieszczą się w tym przedziale.

W piezometrach P-6 i P-9a występowały kilkakrotnie wyższe zawartości żelaza $\mathrm{w}$ wodzie, niż $\mathrm{w}$ pozostałych punktach kontrolnych. Wysokie stężenia żelaza mogą powstawać pod wpływem czynników antropogenicznych lub z przyczyn naturalnych. Wysokim stężeniom żelaza sprzyjają środowiska kwaśne. Żelazo jest pierwiastkiem o wysokim stopniu potencjalnego zagrożenia.

Pod względem zawartości cynku wszystkie badane próbki wody podziemnej występowały na zbliżonym poziomie. Wartość ta oscylowała w granicach $0,1 \mathrm{mg} / \mathrm{dm}^{3}$. Jedynie $\mathrm{w}$ piezometrze P-6 w listopadzie $2014 \mathrm{r}$. odnotowano znacznie wyższą wartość cynku, która wynosiła $0,796 \mathrm{mg} / \mathrm{dm}^{3}$. Wzrost ten mógł być spowodowany rozkopami związanymi $\mathrm{z}$ budową drogi w rejonie piezometru kilka miesięcy wcześniej, podczas których piezometr został zasypany piaskiem oraz zanieczyszczony zanieczyszczeniem pochodzenia organicznego.

Wysokie stężenia niklu $\mathrm{w}$ wodach podziemnych mogą być związane $\mathrm{z}$ antropogenicznymi zanieczyszczeniami. Ścieki z HSW S.A. w Stalowej Woli bogate są w nikiel. Istotną rolę odgrywa opad niklu z emisji przemysłowych występujących głównie w formach rozpuszczalnych w wodzie. Istotnym elementem jest tu emisja do atmosfery, która pochodzi ze spalania węgli. Ze względu na zawartość OWO w badanych próbkach wody podziemnej najwyższą wartość tego parametru uzyskano w marcu $2014 \mathrm{r}$. w otworze piezometrycznym P-6. Woda w piezometrach P-7 i P-8 zawierała stężenia OWO na zbliżonym poziomie.

Kopalnie i Zakłady Przetwórcze Siarki „SIARKOPOL” zlokalizowane w Tarnobrzegu były jednym z największych producentów i eksporterów siarki rodzimej na świecie. Zakład był także znaczącym producentem nawozów mineralnych oraz różnorodnych chemikaliów. Obecnie Kopalnie i Zakłady Przetwórcze Siarki „SIARKOPOL” znajdują się w stanie likwidacji. W 2001 r. w wyniku restrukturyzacji przekształcone zostały przez wiodącego na polskim rynku producenta nawozów mineralnych na ZAKŁADY CHEMICZNE „Siarkopol TARNOBRZEG". Zakładowe składowisko odpadów przemysłowych „SIARKOPOL-Jeziórko” zlokalizowane jest na terenie zabudowy przemysłowej kopalni siarki w Jeziórku - po południowej stronie drogi Tarnobrzeg-Stalowa Wola. Składowisko odpadów jest nieeksploatowane od 2012 r. Na składowisku przyjmowane były odpady przemysłowe obojętne (odpady keku i siarki zanieczyszczonej). Całkowita pojemność obiektu wynosiła $13500,0 \mathrm{Mg}$, zaś powierzchnia była równa 1,6 ha. Składowisko odpadów przemysłowych „SIARKOPOL-Jeziórko” objęte jest monitoringiem wód podziemnych. Pomiary 
do badań zostały wykonane dwa razy w roku. Monitoring czwartorzędowych wód podziemnych prowadzony był w piezometrach Psk 1, Psk 2, Psk 3, Psk 4 zlokalizowanych na terenie składowiska odpadów oraz $\mathrm{w}$ piezometrze P-1k umieszczonym w rejonie zabudowy przemysłowej Kopalni. Jakość wody podziemnej monitorowana była w zakresie: odczynu (pH); twardości ogólnej; przewodności elektrolitycznej właściwe; zawartości siarczanów; zawartości chlorków. Przewodność elektrolityczna właściwa mieściła się w granicach 11232 do $11583 \mu \mathrm{S} / \mathrm{cm}$ (klasa V zakłada wartości $>3000 \mu \mathrm{S} / \mathrm{cm}$ ). Zawartość siarczanów w wodzie osiągała wartości w przedziale 6639 do $11648 \mathrm{mg} / \mathrm{dm}^{3}$, gdzie klasa V zakłada wartości $>500 \mathrm{mg} / \mathrm{dm}^{3}$. W czasie badań woda charakteryzowała się kwaśnym odczynem osiągając wartości <6,5. Parametr ten został zaliczony do IV klasy jakości. Twardość ogólna jest wskaźnikiem nienormowanym rozporządzeniem. Stężenie chlorków w piezometrze było zmienne. W 2012 r. odnotowano gwałtowny wzrost zawartości pierwiastka do $1194 \mathrm{mg} / \mathrm{dm}^{3}$, podczas dalszych pomiarów stężenie chlorków ulegało obniżaniu. Stan chemiczny badanych wód we wszystkich piezometrach uznano za słaby. Wysokie wartości PEW związane są z antropogenicznym lub geogenicznym zanieczyszczeniem wód podziemnych. Przewodność elektrolityczna właściwa jest wskaźnikiem wyrażającym wielkość mineralizacji wód [13].

Ze względu na zawartość w badanej wodzie podziemnej siarczanów stwierdzono, że największe stężenie tego wskaźnika występowało w wodzie pobranej z piezometru P-1k zlokalizowanym w rejonie zabudowy przemysłowej Kopalni. Zawartość siarczanów w pozostałych piezometrach znajdujących się na terenie składowiska odpadów przemysłowych był znacznie niższe. Wysokie stężenie siarczanów w wodzie podziemnej jest skutkiem długoletniej działalności przemysłowej Kopalni i Zakładów Przetwórczych Siarki „SIARKOPOL”. Zakład ten zajmował się produkcją siarki. Siarczany pochodzenia antropogenicznego mogą przenikać do wód bezpośrednio jako ścieki przemysłowe oraz gospodarcze, a także w wyniku ługowania odpadów stałych.

\section{Podsumowanie}

W 2013 r. w otoczeniu składowiska odpadów przemysłowych w Mielcu stwierdzono występowanie wód podziemnych w dobrym stanie chemicznym. W 2014 r. jakość tych wód w piezometrach 4E i 5E uległa pogorszeniu.

Badania przy składowisku odpadów przemysłowych ZTS GAMRAT S.A. wykazały zanieczyszczenie wód podziemnych w piezometrze P-3 w 2013 i 2014 r., w których wody występowały w słabym stanie chemicznym.

Odcieki ze składowisk odpadów przemysłowych w Mielcu i na terenie ZTS GAMRAT S.A. w Jaśle mają kontakt z wodami podziemnymi, na co wskazują istotne różnice pomiędzy wodami na napływie, a wodami na odpływie dla przewodności elektrolitycznej. 
Na terenie HSW S.A. składowisko oddziaływało na wody podziemne. W rejonie składowiska odpadów przemysłowych w latach 2012-2014 występowały wody o słabym stanie chemicznym w piezometrach P-6 i P-7 oraz o stanie dobrym w P-8 i P-9a.

Wody podziemne były zanieczyszczone w rejonie Kopalni i Zakładów Przetwórczych Siarki „SIARKOPOL” w Tarnobrzegu w latach 2013-2014 we wszystkich badanych otworach piezometrycznych. Woda $\mathrm{z}$ piezometru zlokalizowanego $\mathrm{w}$ rejonie zabudowy przemysłowej Kopalni była znacznie bardziej zanieczyszczona, niż woda w piezometrach umieszczonych na terenie składowiska odpadów.

Jakość wód podziemnych z otworów piezometrycznych umieszczonych na terenie składowisk odpadów przemysłowych zależy od rodzaju deponowanych odpadów. Poprawa jakości wód podziemnych może być związana z modernizacją zabezpieczeń składowisk odpadów przemysłowych.

\section{Literatura}

[1] Błaszczyk T., Górski J.: Odpady a problemy zagrożenia i ochrony wód podziemnych, Biblioteka Monitoringu Środowiska, Warszawa 1996.

[2] Chełmicki W.: Woda. Zasoby, degradacja, ochrona, Wydawnictwo Naukowe PWN, Warszawa 2012.

[3] Główny Urząd Statystyczny, Ochrona Środowiska 2014, Zakład Wydawnictw Statystycznych, Warszawa 2014.

[4] Główny Urząd Statystyczny, Rocznik statystyczny województwa podkarpackiego 2014, Rzeszów 2014.

[5] Inspekcja Ochrony Środowiska: Katalog wybranych fizycznych i chemicznych wskaźników zanieczyszczeń wód podziemnych i metod ich oznaczania, Biblioteka Monitoringu Środowiska, Warszawa 2013.

[6] Kazimierski B.: Monitoring wód podziemnych - przykład zastosowania lokalnego, Przegląd geologiczny nr 4/2008.

[7] Macioszczyk A.: Podstawy hydrogeologii stosowanej, Wydawnictwo Naukowe PWN, Warszawa 2006.

[8] Malina G.: Likwidacja zagrożenia środowiska gruntowo-wodnego na terenach zanieczyszczonych, Polskie Zrzeszenie Inżynierów i Techników Sanitarnych O/Wielkopolski w Poznaniu, Poznań 2011.

[9] Paczyński B., Sadurski A.: Hydrogeologia regionalna Polski T.I. Wody słodkie, Państwowy Instytut Geologiczny, Warszawa 2007.

[10] Rozporządzenie Ministra Środowiska z dnia 23 lipca 2008 r. w sprawie kryteriów i sposobu oceny stanu wód podziemnych (Dz. U. 2008 Nr 143, poz. 896).

[11] Rozporządzenie Ministra Środowiska z dnia 30 kwietnia 2013 r. w sprawie składowisk odpadów (Dz. U. 2013 poz. 523).

[12] Sobik K.: Badanie wpływu składowisk odpadów na środowisko gruntowo-wodne na przykładzie wybranych obiektów zlokalizowanych w obrębie zlewni Dunajca, Rozprawa doktorska, Kraków 2007. 
[13] Wojewódzki Inspektorat Ochrony Środowiska w Rzeszowie, Raport o stanie środowiska w województwie podkarpackim w 2013 roku, Biblioteka Monitoringu Środowiska, Rzeszów 2013.

[14] Zarzycki R., Imbierowicz M., Stelmachowski M.: Wprowadzenie do inżynierii i ochrony środowiska 1. Ochrona środowiska naturalnego, Wydawnictwo Naukowo-Techniczne, Warszawa 2007.

\title{
ANALYSIS OF UNDERGROUND WATER CONTAMINATION WITH INDUSTRIAL WASTE PRODUCTS IN THE TERRITORY OF PODKARPACKIE REGION
}

\begin{abstract}
S u m m a r y
In the article the analysis of underground water contamination with industrial waste products which occur in the Podkarpackie region, especially in Rzeszów, Stalowa Wola, Przemyśl, Mielec, Dębica and Tarnobrzeg was presented. The underground water contamination is most frequently a consequence of unintended incidents such as a crack and a leakage of pipelines and sewage systems, a damage of tanks with dangerous substances, failures of technological installations etc. Some protection and monitoring methods of underground water from degradation were presented. It was shown that areas of industrial plants, where waste was stored as well as dangerous substances were poured or transported, were one of the causes of the underground water contamination in the territory of Podkarpackie region. The major branches of industry are aviation, electromechanical, agricultural, food and chemical. The underground water contamination rates vary depending on the type of industry. They depend on the character of production, products manufactured, raw materials used, technologies applied, transport, storage, sewage treatment methods, waste utilization, etc. In Podkarpackie region the largest number of industrial wastes was generated in Dębicki, Stalowowolski, Mielecki and Rzeszowski counties. The smallest number of industrial wastes was generated in Lubaczowski, Bieszczadzki and Kolbuszowski counties. Rzeszow was the city with the largest number of industrial waste. In the thesis the underground water contamination is analyses with respect to the generated industrial waste as well as refuse collection depots. The quality of underground water in pressure holes situated in the areas of refuse collection depots depends on the type of stored waste. The improvement of underground water quality can be related to the modernization of protection of landfill sites.
\end{abstract}

Keywords: underground water, contamination, waste, industrial plants

Przestano do redakcji: 23.05 .2015 r.

Przyjęto do druku: $30.10 .2015 \mathrm{r}$.

DOI: $10.7862 / \mathrm{rb} .2015 .105$ 